\title{
Kombinasi Synthetic Minority Oversampling Technique (SMOTE) dan Neural Network Backpropagation untuk menangani data tidak seimbang pada prediksi pemakaian alat kontrasepsi implan
}

\section{Combination of Synthetic Minority Oversampling Technique (SMOTE) and Backpropagation Neural Network to handle imbalanced class in predicting the use of contraceptive implants}

\author{
Mustaqim Mustaqim a, Budi Warsito ${ }^{b}$, Bayu Surarso ${ }^{c}$ \\ a Sistem Informasi, Universitas Diponegoro, Semarang, Indonesia \\ ${ }^{b}$ Statistika, Universitas Diponegoro, Semarang, Indonesia \\ -Matematika, Universitas Diponegoro, Semarang, Indonesia \\ email: ${ }^{a d i m a s t h a n @ g m a i l . c o m, b b u d i w r s t 2 @ g m a i l . c o m, c ~ b a y u s u r a r s o @ y a h o o . c o m ~}$
}

\begin{tabular}{l}
\hline I N F O A R T I K E L \\
\hline Sejarah artikel: \\
Menerima 26 April 2019 \\
Revisi 6 Agustus 2019 \\
Diterima 11 September 2019 \\
Online 12 September 2019
\end{tabular}

Kata kunci

backpropagation

imbalance class

implan

prediksi

SMOTE

Keywords:

backpropagation

imbalance class

implant

predict

SMOTE

Style APA dalam menyitasi artikel ini:

Mustaqim, M., Warsito, B.,

\& Surarso, B. (2019).

Kombinasi Synthetic

Minority Oversampling

Technique (SMOTE) dan

Neural Network

Backpropagation untuk

\begin{abstract}
ABSTRAK
Kegagalan akibat pemakaian alat kontrasepsi implan merupakan terjadinya kehamilan pada wanita saat menggunakan alat kontrasepsi secara benar. Kegagalan pemakaian kontrasepsi implan tahun 2018 secara nasional sejumlah 1.852 pengguna atau $4 \%$ dari 41.947 pengguna. Rasio angka kegagalan dan keberhasilan pemakaian kontrasepsi implan yang cenderung tidak seimbang (imbalance class) membuatnya sulit diprediksi. Ketidakseimbangan data terjadi jika jumlah data suatu kelas lebih banyak dari data lain. Kelas mayor merupakan jumlah data yang lebih banyak, sedangkan kelas minor jumlahnya lebih sedikit. Algoritma klasifikasi akan mengalami penurunan performa jika menghadapi kelas yang tidak seimbang. Synthetic Minority Oversampling Technique (SMOTE) digunakan untuk menyeimbangkan data kegagalan pemakaian kontrasepsi implan. SMOTE menghasilkan akurasi yang baik dan efektif daripada metode oversampling lainnya dalam menangani imbalance class karena mengurangi overfitting. Data yang sudah seimbang kemudian diprediksi dengan Neural Network Backpropagation. Sistem prediksi ini digunakan untuk mendeteksi apakah seorang wanita mengalami kehamilan atau tidak jika menggunakan kontrasepsi implan. Penelitian ini menggunakan 300 data, terdiri dari 285 data mayor (tidak hamil) dan 15 data minor (hamil). Dari 300 data dibagi menjadi dua bagian, 270 data latih dan 30 data uji. Dari 270 data latih, terdapat 13 data latih minor dan 257 data latih mayor. Data latih minor pada data latih diduplikasi sebanyak data pada kelas mayor sehingga jumlah data latih menjadi 514, terdiri dari 257 data mayor, 13 data minor asli, dan 244 data minor buatan. Sistem prediksi menghasilkan nilai akurasi sebesar $96,1 \%$ pada epoch ke-500 dan 1.000. Implementasi kombinasi SMOTE dan Neural Network Backpropagation terbukti mampu memprediksi pada imbalance class dengan hasil prediksi yang baik.
\end{abstract}

\section{ABSTRACT}

The failed contraceptive implant is one of the sources of unintended pregnancy in women. The number of users experiencing contraceptive-implant failure in 2018 was 1,852 nationally or $4 \%$ out of 41,947 users. The ratio between failure and success rates of contraceptive implant, which tended to be unbalanced (imbalance class), made it difficult to predict. Imbalance class will occur if the amount of data in one class is bigger than that in other classes. Major classes represent a bigger amount of data, while minor classes are 
menangani data tidak seimbang pada prediksi pemakaian alat kontrasepsi implan. Register: Jurnal Ilmiah Teknologi Sistem Informasi, 116-127. smaller ones. The imbalance class will decrease the performance of the classification algorithm. The Synthetic Minority Oversampling Technique (SMOTE) was used to balance the data of the contraceptive implant failures. SMOTE resulted in better and more effective accuracy than other oversampling methods in handling the imbalance class because it reduced overfitting. The balanced data were then predicted using Backpropagation neural networks. The prediction system was used to detect if a woman using a contraceptive implant was pregnant or not. This study used 300 data, consisting of 285 major data (not pregnant) and 15 minor data (pregnant). Of 300 data, two groups of data were formed: 270 training data and 30 testing data. Of 270 training data, 13 were minor training data and 257 were major training data. The minor training data in the training data were duplicated as much as the number of data in major classes so that the total training data became 514, consisting of 257 major data, 13 original minor data, and 244 artificial minor data. The prediction system resulted in an accuracy of $96.1 \%$ on the 500th and 1,000th epochs. The combination of SMOTE and Backpropagation Neural Network was proven to be able to make a good prediction result in imbalance class.

(c) 2019 Register: Jurnal IImiah Teknologi Sistem Informasi. Semua hak cipta dilindungi undang-undang.

\section{Pendahuluan}

Kegagalan akibat pemakaian alat kontrasepsi implan merupakan terjadinya kehamilan pada wanita saat menggunakan alat kontrasepsi secara benar. Kegagalan pemakaian alat kontrasepsi implan setiap tahunnya cenderung di bawah 5\% dari angka keberhasilannya, seperti contoh pada 2018, angka kegagalan secara nasional sejumlah 1.852 pengguna atau $4 \%$ dari total pengguna kontrasepsi implan yang berhasil sebanyak 41.947 pengguna (BKKBN, 2013). Rasio angka kegagalan dan keberhasilan pemakaian kontrasepsi implan yang cenderung tidak seimbang membuatnya sulit diprediksi. Penelitian imbalance class (kelas tidak seimbang) telah banyak dilakukan, antara lain Mutrofin, Mu'alif, Ginardi, dan Fatichah (2019) yang mengusulkan penerapan algoritma k-Nearest Neighbor pada kasus Educational Data Mining serta Liu, Li, dan Zhou (2013) yang mengusulkan bahwa mengatasi masalah multiclass lebih sulit dari dua kelas.

Kelas dikatakan tidak seimbang jika rasio objek suatu kelas data lebih banyak dibandingkan dengan kelas lain. Kelas mayor merupakan jumlah data yang lebih banyak, sedangkan kelas minor yang jumlahnya lebih sedikit. Zhu, Lin, dan Liu (2017) mengusulkan metode Synthetic Minority Oversampling Technique (SMOTE) sebagai solusi untuk menangani imbalance class. Penerapan algoritma yang mengabaikan imbalance class akan menghasilkan prediksi yang baik pada kelas mayor, sedangkan kelas minor diabaikan (Chen, Fang, Shang, \& Tang, 2018). Algoritma klasifikasi akan mengalami penurunan performa jika menghadapi imbalance class (García, Sánchez, \& Mollineda, 2012).

Algoritma klasifikasi yang paling populer digunakan dalam pengklasifikasian ialah Neural Network (NN), Logistic Regression (LR), Decision Tree (DT), dan Support Vector Machine (SVM). NN atau Jaringan Saraf Tiruan (JST) merupakan model algoritma komputasi intensif yang mengubah input menjadi output menggunakan jaringan sederhana yang saling terhubung dengan elemen proses yang disebut neuron dan unit/node (Thammasiri, Delen, Meesad, \& Kasap, 2014). Konsep dari LR menguji hubungan linear antara variabel dependen dan independen. DT bekerja dengan mengubah data menjadi pohon dan aturan-aturan keputusan. DT bekerja dengan cara melakukan break down keputusan yang kompleks menjadi simple, sehingga menghasilkan keputusan yang menggambarkan solusi dari permasalahan. Prinsip dari SVM merupakan klasifikasi linier, kemudian dikembangkan untuk mengatasi masalah nonlinier dengan cara memasukkan kernel trick pada ruang kerja berdimensi tinggi.

Penelitian terkait perbandingan 4 kinerja algoritma klasifikasi dalam menangani imbalance class telah dilakukan dengan nilai akurasi: NN dengan SMOTE 85\%, DT dengan SMOTE 89\%, LR dengan SMOTE 80\%, dan SVM 90\% (Thammasiri, Delen, Meesad, \& Kasap, 2014). Backpropagation adalah model yang biasa digunakan untuk memprediksi penyakit dan gejala-gejalanya.

Implementasi NN Backpropagation dalam bidang kesehatan, di antaranya deteksi Tuberculosis (TBC) (Purnamasari, Dwijanto, \& Sugiharti, 2013), demam berdarah (Widodo, Rachman, \& Amelia, 2014), kanker serviks (Susanto, 2012) masing-masing dengan tingkat akurasi 100\%; 74\%; dan 95,14\%.

Berdasarkan latar belakang tersebut, penelitian ini menggunakan metode kombinasi Synthetic Minority Oversampling Technique (SMOTE) dan Neural Network Backpropagation untuk memprediksi keberhasilan pemakaian alat kontrasepsi implan. 


\section{State of the Art}

Permasalahan ketidakseimbangan kelas (imbalance class) adalah kondisi pada dataset kelas dengan perbedaan tinggi. Masalah ini sangat memengaruhi kinerja prediksi model algoritma klasifikasi karena model cenderung memprediksi dengan tingkat akurasi tinggi pada kelas yang lebih besar jumlahnya (Sanguanmak \& Hanskunatai, 2016). Model yang dibuat dengan imbalance class akan menghasilkan prediksi kelas minor yang rendah. Informasi yang ada pada kelas mayor mendominasi kelas minor, sehingga informasi pada kelas minor cenderung diabaikan dalam sistem klasifikasi (Jian, Gao, \& Ao, 2016). Untuk menangani imbalance class pada suatu dataset, ada dua pendekatan, yaitu level algoritma dan level data. Pada level algoritma, proses berjalan dengan menyesuaikan alur algoritma yang ada melalui pengklasifikasian agar data mayor dan minor seimbang. Pada pendekatan level data, ada macam-macam teknik resampling dan duplikasi data untuk menyeimbangkan data kelas minor pada data latih (Zhang, Liu, Gong, \& Jin, 2011). Macam-macam teknik resampling adalah undersampling dan oversampling. Undersampling merupakan teknik menyeimbangkan kelas dengan mengurangi instance pada kelas mayor. Undersampling akan mengurangi risiko hilangnya informasi penting dalam pengambilan keputusan dari machine learning. Oversampling merupakan teknik menyeimbangkan kelas dengan menduplikasi kelas minor secara acak. Kekurangan dari oversampling yaitu akan mengalami overfitting karena duplikasi kelas minor sama persis (Yap, et al., 2014). Metode SMOTE ditawarkan untuk menangani overfitting, yaitu dengan memanfaatkan ketetanggaan terdekat dari jumlah oversampling yang dikehendaki.

\subsection{Imbalance Class}

Ketidakseimbangan kelas pada dataset kecil sangat merugikan dalam penelitian di data mining, karena machine learning menghadapi kesulitan saat mengklasifikasikan kelas minoritas dengan benar. Kelas dikatakan tidak seimbang, jika rasio objek suatu kelas data lebih banyak dibandingkan dengan kelas lain. Kelas mayor merupakan kelas yang jumlah datanya lebih banyak, sedangkan kelas minor yang jumlah datanya lebih sedikit. Kebanyakan algoritma berasumsi bahwa distribusi kelas yang diuji sudah seimbang, sehingga salah dalam mengklasifikasi nilai pada tiap kelas. Menurut (Li \& Sun, 2012), jika proporsi sampel kelas minoritas kurang dari 35\% dari dataset, dikategorikan sebagai imbalance class. Sementara menurut (He \& Ma, 2013), kelas sudah dapat dikatakan imbalance class, jika perbandingan data mayor dua kali ditambah satu dari kelas minornya $(\mathbf{2 n}+\mathbf{1})$.

\subsection{Synthetic Minority Oversampling Technique (SMOTE)}

Pendekatan Synthetic Minority Oversampling Technique (SMOTE) merupakan teknik untuk menyeimbangkan kelas yang berbeda dengan oversampling. Pendekatan SMOTE membuat duplikasi data minor agar seimbang dengan data mayor. Teknik SMOTE mampu mengurangi overfitting yang merupakan kelemahan dari teknik oversampling (Shen, Lin, \& Huang, 2016). Data duplikasi atau sintesis dibuat berdasarkan faktor $k$-tetangga terdekat ( $k$-Nearest Neighbor).

\subsection{Backpropagation}

Jaringan Saraf Tiruan (JST) merupakan model algorithmic komputasi intensif yang mengubah input menjadi output menggunakan jaringan sederhana yang saling terhubung dengan elemen proses yang disebut neuron dan unit/node (Thammasiri, Delen, Meesad, \& Kasap, 2014). Pemodelan menggunakan JST dapat menghasilkan analisis lebih baik dan efektif dalam prediksi (Chen, et al., 2014). Hal ini dikarenakan model mampu bekerja dengan baik pada data nonlinier dan data seri. Backpropagation merupakan salah satu model JST atau Neural Network (NN) multilayer. Struktur Backpropagation yang umum digunakan adalah Multilayer Perceptron (MLP). Dalam jaringan MLP, ada tiga jaringan neuron, yaitu input, hidden, dan output yang dihubungkan oleh bobot. JST Backpropagation melatih jaringan untuk memperoleh keseimbangan dalam mengenali pola yang digunakan selama pelatihan dan merespons secara benar terhadap pola masukan yang serupa, tetapi tidak sama dengan pola pelatihan (Gholami, Cai, \& Brennan, 2013). Algoritma pelatihan Backpropagation dibagi menjadi tiga fase (Sermpinis, Dunis, Laws, \& Stasinakis, 2012), yaitu 1) Fase propagasi maju (feedforward) pola masukan. Pola masukan dihitung maju dari lapisan (layer) masukan hingga layer keluaran dengan fungsi aktivasi yang ditentukan; 2) Fase propagasi mundur (Backpropagation) dimulai dari garis yang berhubungan langsung dengan unit-unit pada layer keluaran; 3) Fase perubahan nilai bobot, perubahan bobot suatu 
garis didasarkan pada faktor $\boldsymbol{\delta}$ neuron di layer atasnya. Ketiga fase tersebut diulang-ulang hingga kondisi penghentian dipenuhi. Umumnya, kondisi penghentian berupa jumlah iterasi (epoch) atau kesalahan. Arsitektur standar Backpropagation ditunjukkan pada Gambar 1.

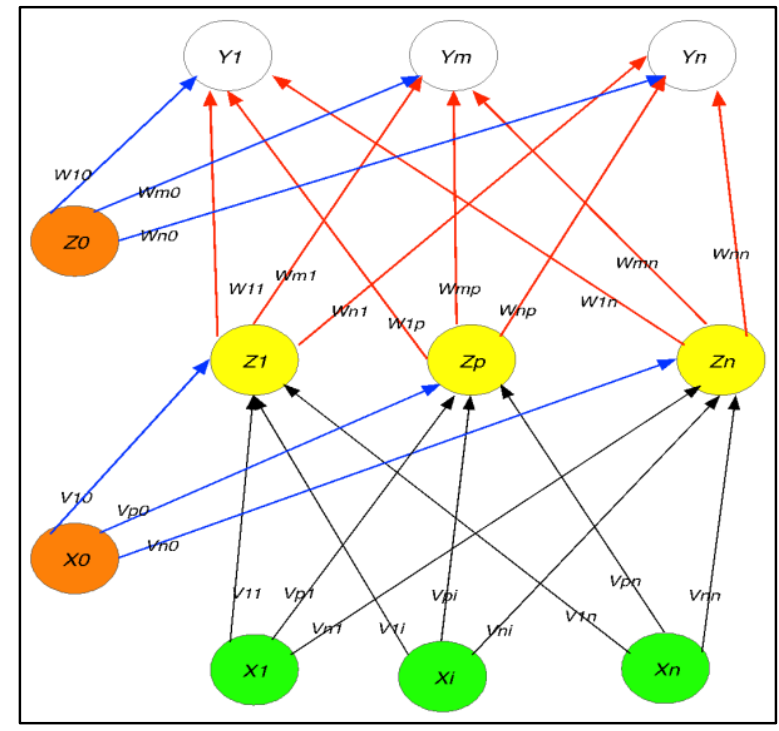

Gambar 1. Arsitektur standar Backpropagation

\section{Metode Penelitian}

\subsection{Kerangka Kerja Sistem Prediksi}

Penelitian prediksi pemakaian alat kontrasepsi implan menggunakan kombinasi SMOTE dan NN Backpropagation dimulai dari input data dari variabel implan $\boldsymbol{x}_{\mathbf{1}}$ sampai $\boldsymbol{x}_{\mathbf{9}}$ dilakukan prapengolahan dengan mengonrversi data menjadi angka-angka, sehingga memudahkan proses komputasi dalam sistem. Data yang telah dikonversi kemudian dibagi menjadi dua bagian, yaitu data testing dan training. Pada data training dilakukan proses duplikasi data kelas minor untuk menyeimbangkan dengan data kelas mayor melalui metode SMOTE, sedangkan pada data testing tidak dilakukan duplikasi data. Setelah data training telah seimbang, dilakukan proses training dan testing dengan NN Backpropagation untuk mendapatkan nilai akurasi yang terbaik. Output yang dihasilkan berupa hasil prediksi pemakaian alat kontrasepsi implan. Dalam hal ini, sistem akan mendeteksi seorang wanita bila menggunakan kontrasepsi implan dengan ciri-ciri riwayat pemeriksaan medis akan berhasil (tidak hamil) atau gagal (hamil). Evaluasi sistem prediksi menggunakan confusion matrix dan 10-fold cross validation. Konsep kerangka kerja sistem ditunjukkan pada Gambar 2.

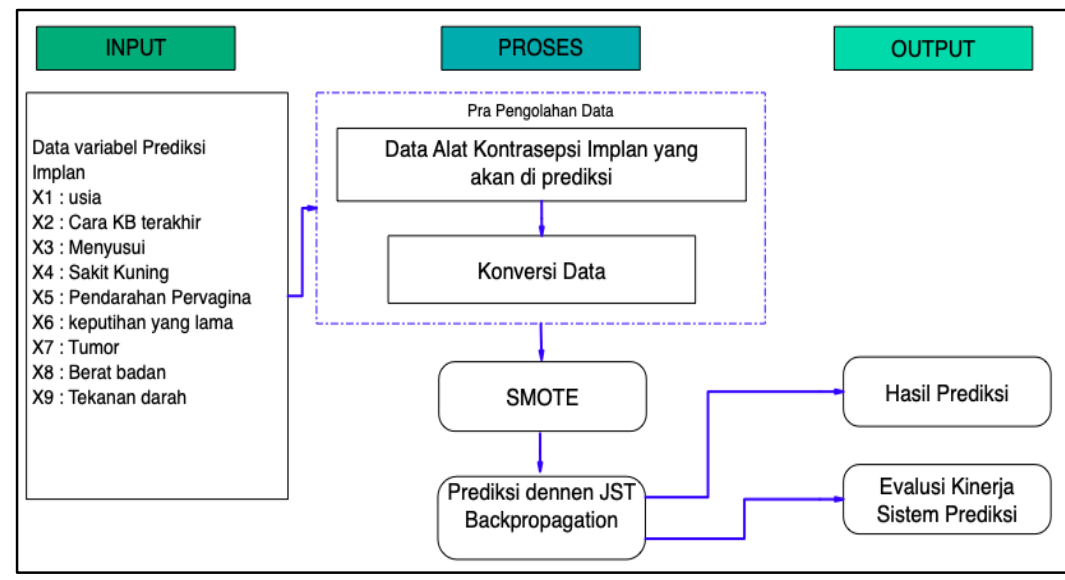

Gambar 2. Kerangka kerja sistem prediksi implan

\section{2. $\quad$ Data dan Variabel Penelitian}

Data penelitian diambil dari kartu status peserta Keluarga Berencana K4/KB yang berasal dari hasil survei Petugas Lapangan Keluarga Berencana (PLKB) Badan Kependudukan dan Keluarga Berencana

Kombinasi Synthetic Minority Oversampling Technique (SMOTE) dan Neural Network ... http://doi.org/10.26594/register.v5i2.1705 (c) 2019 Register: Jurnal IImiah Teknologi Sistem Informasi. Semua hak cipta dilindungi undang-undang. 
Nasional (BKKBN). Dari kartu K4/KB tersebut, diambil 9 variabel penentu, yaitu $\boldsymbol{x}_{\mathbf{1}}$ sampai $\boldsymbol{x}_{\mathbf{9}}$. Data yang digunakan untuk prediksi alat kontrasepsi implan sebanyak 300 data, 285 data berhasil (tidak hamil) dengan target $(\boldsymbol{T}=\mathbf{0})$ dan 15 data gagal (hamil) dengan target $(\boldsymbol{T}=\mathbf{1})$. Variabel $\boldsymbol{x}_{\mathbf{1}}$ sampai $\boldsymbol{x}_{\mathbf{9}}$ dengan nilai input dan target prediksi ditunjukkan pada Tabel 1.

Tabel 1. Variabel dan nilai input target prediksi

\begin{tabular}{|c|c|c|c|}
\hline Variabel & Deskripsi & Kategori & *Nilai input \\
\hline \multirow[t]{3}{*}{ Usia $\left(x_{1}\right)$} & Usia saat dipasangi implan & 19-30 Tahun & 0 \\
\hline & & 31-40 Tahun & 0 \\
\hline & & 41-49 Tahun & 0,5 \\
\hline \multirow[t]{2}{*}{ Cara KB terakhir $\left(x_{2}\right)$} & Cara KB yang terakhir digunakan & Pil & 0 \\
\hline & & Suntik & 0,3 \\
\hline \multirow[t]{2}{*}{ Menyusui $\left(x_{3}\right)$} & Saat dipasang kontrasepsi implan & Ya & 0 \\
\hline & & Tidak & 1 \\
\hline \multirow[t]{2}{*}{ Sakit kuning $\left(x_{4}\right)$} & Riwayat sakit kuning & Ya & 1 \\
\hline & & Tidak & 0 \\
\hline \multirow[t]{2}{*}{ Perdarahan pervaginam $\left(x_{5}\right)$} & Riwayat perdarahan pervaginam & Ya & 0,5 \\
\hline & & Tidak & 0 \\
\hline \multirow[t]{2}{*}{ Keputihan lama $\left(x_{6}\right)$} & Riwayat keputihan lama & $\mathrm{Ya}$ & 0,5 \\
\hline & & Tidak & 0 \\
\hline \multirow[t]{2}{*}{ Tumor (payudara, rahim) $\left(x_{7}\right)$} & Riwayat tumor (payudara, rahim, dan indung & Ya & 0,5 \\
\hline & telur) & Tidak & 0 \\
\hline \multirow[t]{5}{*}{ Berat badan $\left(x_{8}\right)$} & Berat badan pasien saat dipasangi implan & $<40 \mathrm{Kg}$ & 0 \\
\hline & & $40-55 \mathrm{~kg}$ & 0 \\
\hline & & $56-64 \mathrm{~kg}$ & 0 \\
\hline & & $65-70 \mathrm{~kg}$ & 0,5 \\
\hline & & $>70 \mathrm{~kg}$ & 1 \\
\hline \multirow[t]{6}{*}{ Tekanan darah $\left(x_{9}\right)$} & Tekanan darah saat pasien dipasangi kontrasepsi & $<90 / 60 \mathrm{mmHg}$ & 0 \\
\hline & implan & 90-120/60-70 mmHg & 0 \\
\hline & & $121-139 / 80-89 \mathrm{mmHg}$ & 0 \\
\hline & & $140-159 / 90-99 \mathrm{mmHg}$ & 0,5 \\
\hline & & $\begin{array}{c}160-179 / 100-119 \\
\mathrm{mmHg}\end{array}$ & 1 \\
\hline & & $>180 / 120 \mathrm{mmHg}$ & 1 \\
\hline \multirow[t]{2}{*}{ Target $(T)$} & Apakah pasien gagal (hamil)/ berhasil (tidak & Gagal (hamil) & 1 \\
\hline & hamil) & Berhasil (tidak hamil) & 0 \\
\hline
\end{tabular}

*Sumber: Tim pakar medis yang berkompeten dalam bidang Keluarga Berencana

Data yang digunakan untuk prediksi kontrasepsi implan kemudian dikonversi dengan acuan Tabel 1. Konversi dilakukan untuk mengubah data kualitatif yang terdapat pada variabel menjadi angka untuk memudahkan dalam sistem komputasi. Data yang telah dikonversi kemudian dibagi menjadi dua bagian, yaitu data testing dan training. Pada data training, dilakukan proses duplikasi data minor untuk menyeimbangkan dengan data pada kelas mayor.

Dari 300 data, 285 data mayor/berhasil $(T=0)$ dan 15 data minor/gagal $(T=1)$. Data kelas mayor dan minor tersebut kemudian sistem secara acak membagi menjadi 2 bagian, yaitu data training dan testing dengan rincian: data testing implan 30 data, 28 data mayor/berhasil $(T=0), 2$ data minor/gagal $(T=1)$ dan data training implan sebanyak 270 data, 257 data mayor $(T=0), 13$ data minor/gagal $(T=$ 1). Data training kelas minor sebanyak 13 data dilakukan duplikasi data dengan SMOTE menjadi 244 data minor buatan (synthetic), sehingga data kelas minor menjadi 257 data atau setara data kelas mayor, dengan rincian 13 data minor asli dan 244 data minor buatan. Alur proses duplikasi data kelas minor dengan metode SMOTE ditunjukkan pada Gambar 3. Data testing dan data training yang sudah seimbang kemudian diprediksi dengan menggunakan NN Backpropagation.

\subsection{Algoritma Neural Network Backpropagation}

Algoritma pelatihan Backpropagation diuraikan sebagai berikut (Budayawan, Yuhandri, \& Nurcahyo, 2019):

a. Step 0: Tentukan semua nilai bobot dengan bilangan random kecil, epoch $=1$, learning rate $(\alpha)$, tentukan jumlah hidden layer (Z) dan tentukan kondisi penghentian. Penghentian merupakan maksimum epoch dan nilai akurasi.

b. Step 1: Jika epoch dan nilai akurasi belum sesuai, lakukan Step 2 sampai Step 9. 
c. Step 2: Setiap pasang data latih $(1-\alpha$, di mana $\alpha$ merupakan jumlah data latih), lakukan Step 3 sampai Step 8.

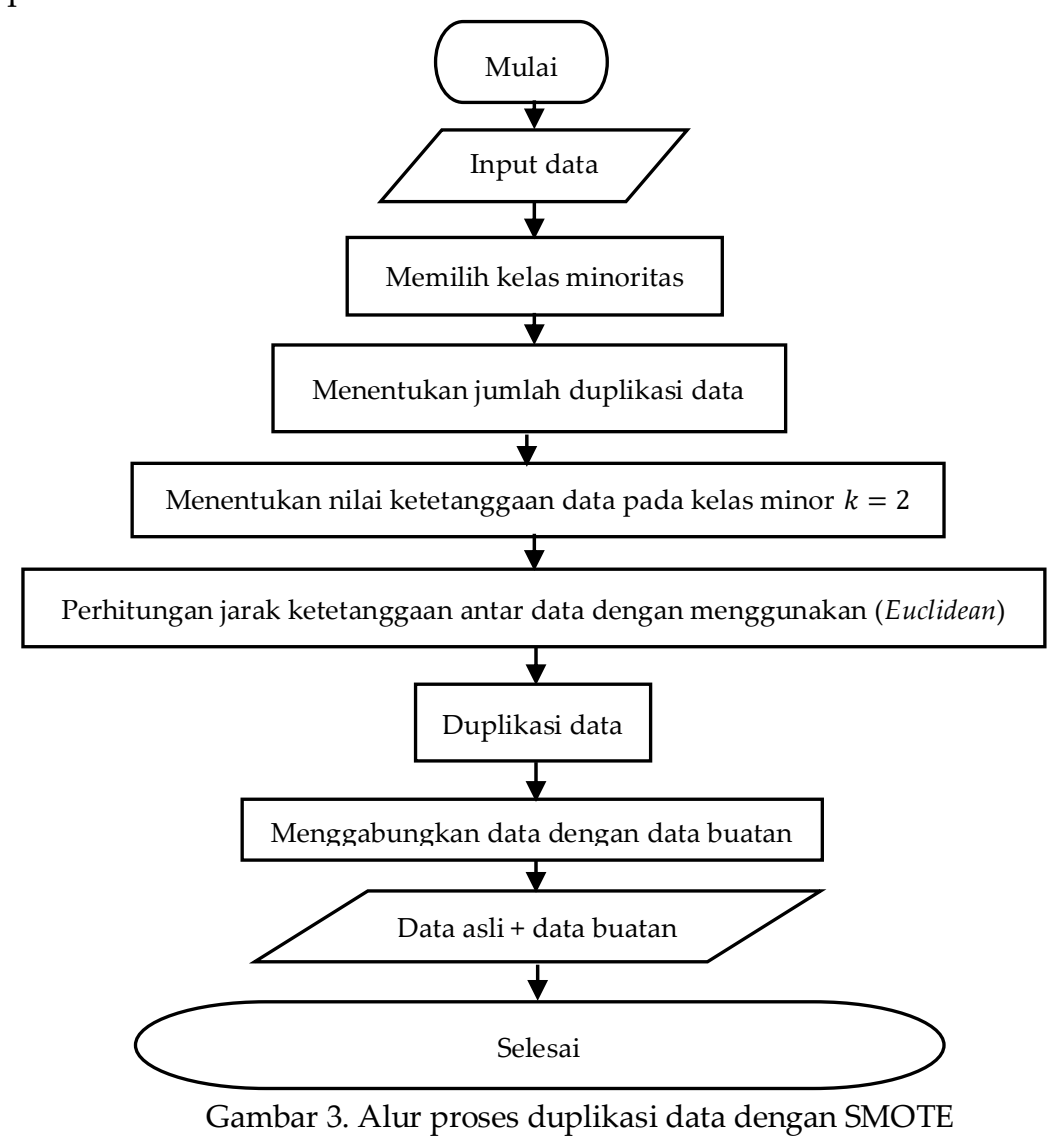

d. Fase I: Propagasi maju

Step 3: Tiap unit input menerima sinyal dan meneruskannya ke hidden layer di atasnya.

Step 4: Hitung semua output pada hidden layer $z_{p}(p=1,2, \ldots, n)$ dengan Persamaan 2,

znet $_{p}=v_{p 0}+\sum_{i=1}^{n} x_{i} v_{p i}$

Persamaan 1 digunakan untuk menghitung Persamaan 2,

$z_{p}=f\left(\right.$ znet $\left._{p}\right)=\frac{1}{1+e^{-z n e t} j}$

Step 5: Hitung semua output jaringan di unit $y_{m}(m=1,2, \ldots, n)$ dengan Persamaan 4,

ynet $_{m}=w_{m 0}+\sum_{m=1}^{p} z_{p} w_{m p}$

Persamaan 3 digunakan untuk menghitung Persamaan 4,

$y_{m}=f\left(\right.$ ynet $\left._{m}\right)=\frac{1}{1+e^{- \text {ynet }_{m}}}$

e. Fase II: Propagasi mundur

Step 6: Hitung faktor $\delta$ unit keluaran berdasarkan kesalahan di setiap unit keluaran $\delta_{m}(m=$ $1,2, \ldots, n)$ menggunakan Persamaan 5,

$\delta_{m}=\left(t_{m}-y_{m}\right) f^{\prime}\left(\mathrm{ynet}_{m}\right)=\left(t_{m}-y_{m}\right) y_{m}\left(1-y_{m}\right)$

Hitung perubahan bobot $\Delta w_{m p}$ dengan learning rate $(\alpha)$ dengan Persamaan 6 ,

$\Delta w_{m p}=\alpha \delta_{m} z_{p} \quad m=1,2, \ldots, n$ dan $p=0,1, \ldots, n$.

Step 7: Hitung faktor $\delta$ unit tersembunyi berdasarkan kesalahan di tiap unit tersembunyi $\delta_{p}(p=$ $1,2, \ldots, n)$ dengan Persamaan 8 ,

Snet $_{p}=\sum_{m=1}^{n} \delta_{m} w_{m p}$

Persamaan 7 digunakan untuk menghitung Persamaan 8,

$\delta_{p}=\operatorname{\delta net}_{p} f^{\prime}\left(\right.$ znet $\left._{p}\right)=$ Snet $_{p} z_{p}\left(1-z_{p}\right)$

Hitung suku perubahan bobot $v_{p i}$ dengan laju percepatan $\alpha$ dengan Persamaan 9, 


$$
\Delta v_{p i}=\alpha \delta_{p} x_{i} \quad p=1,2, \ldots, n ; i=0,1, \ldots, n
$$

f. Fase III: Perubahan bobot

Step 8: Hitung semua perubahan bobot garis yang menuju ke unit keluaran dengan Persamaan 10,

$$
w_{m p}(\text { baru })=w_{m p}(\text { sekarang })+\Delta w_{m p} \quad m=1,2, \ldots, n ; p=0,1, \ldots, n
$$

Perubahan bobot garis yang menuju ke unit tersembunyi dengan menggunakan Persamaan 11,

$$
v_{m p}(\text { baru })=v_{m p}(\text { sekarang })+\Delta v_{p i} \quad p=1,2, \ldots, n ; i=0,1, \ldots, n
$$

g. Step 9: Perbaharui nilai epoch dengan Persamaan 12,

epoch $=$ epoch +1

Hitung nilai akurasi dengan Persamaan 13,

$$
\text { akurasi }=\frac{\text { jumlah data latih yang dikenali }}{\text { jumlah seluruh data latih }} \times 100 \%
$$

\subsection{Evaluasi Sistem Prediksi}

Penelitian ini menggunakan confusion matrix dan 10-fold cross validation untuk evaluasi sistem prediksi. Confusion matrix digunakan dalam mengevaluasi kinerja suatu algoritma klasifikasi dengan cara membandingkan hasil prediksi yang dilakukan oleh sistem dengan hasil prediksi yang seharusnya seperti pada Tabel 2. TP (True Positive) merupakan data positif yang terdeteksi dengan benar, TN (True Negative) merupakan jumlah data negatif yang terdeteksi dengan benar, FP (False Positive) merupakan data negatif yang terdeteksi sebagai data positif, dan FN (False Negative) merupakan jumlah data

\begin{tabular}{|c|c|c|c|c|c|c|c|c|c|}
\hline 1 & 2 & 3 & 4 & 5 & 6 & 7 & 8 & 9 & 10 \\
\hline 1 & 2 & 3 & 4 & 5 & 6 & 7 & 8 & 9 & 10 \\
\hline 1 & 2 & 3 & 4 & 5 & 6 & 7 & 8 & 9 & 10 \\
\hline 1 & 2 & 3 & 4 & 5 & 6 & 7 & 8 & 9 & 10 \\
\hline 1 & 2 & 3 & 4 & 5 & 6 & 7 & 8 & 9 & 10 \\
\hline 1 & 2 & 3 & 4 & 5 & 6 & 7 & 8 & 9 & 10 \\
\hline 1 & 2 & 3 & 4 & 5 & 6 & 7 & 8 & 9 & 10 \\
\hline 1 & 2 & 3 & 4 & 5 & 6 & 7 & 8 & 9 & 10 \\
\hline 1 & 2 & 3 & 4 & 5 & 6 & 7 & 8 & 9 & 10 \\
\hline 1 & 2 & 3 & 4 & 5 & 6 & 7 & 8 & 9 & 10 \\
\hline & & Data & & & & & & & \\
\hline & & Data & jjian & & & & & & \\
\hline
\end{tabular}
kebalikan dari FP. Untuk mengukur kinerja confusion matrix digunakan 3 persamaan untuk mencari nilai akurasi dengan menggunakan Persamaan 14, presisi dengan menggunakan Persamaan 15, dan recall dengan menggunakan Persamaan 16.

Gambar 4. Skema 10-fold cross validation

Akurasi $=\frac{T P+T N}{T P+T N+F N+F P} \times 100 \%$

Presisi $=\frac{T P}{T P+F P} \times 100 \%$

Recall $=\frac{T P}{T P+F N} \times 100 \%$

Penelitian ini juga menggunakan metode 10-fold cross validation untuk evaluasi sistem prediksi. Prinsip evalusi dengan 10-fold cross validation dengan membagi dataset menjadi 10 bagian, 1 bagian data uji dan 9 bagian lainnya sebagai data latih. Dataset yang telah dibagi menjadi 2 bagian tersebut 
dilakukan pelatihan sebanyak 10 kali, kemudian hasilnya dihitung nilai rata-rata akurasinya. Gambar 4 merupakan ilustrasi dari 10-fold cross validation.

Tabel 2. Confusion matrix

\begin{tabular}{llcc}
\hline & & \multicolumn{2}{c}{ Prediction } \\
\hline \multirow{2}{*}{ Actual } & & Positive & Negative \\
& Positive & TP & FN \\
& Negative & FP & TN \\
\hline
\end{tabular}

\section{Hasil dan Pembahasan}

\subsection{Hasil Pelatihan Sistem Prediksi}

Hasil pelatihan sistem prediksi dengan NN Backpropagation menggunakan 514 data training yang terdiri dari 257 mayor, 13 data minor asli dan 244 data minor buatan. Model NN Backpropagation menggunakan arsitektur terbaik berdasarkan hasil latih, yaitu 3 hidden layer, learning rate $(\boldsymbol{\alpha})=\mathbf{0}, \mathbf{1}$; Momentum $=\mathbf{0 , 9}$ dan data dilakukan 5 kali percobaan training pada 10,50,100,500, dan 1.000 epoch didapat nilai akurasi terbaik sebesar $96,4 \%$ pada $\mathbf{5 0 0}$ dan $\mathbf{1 . 0 0 0}$ epoch. Beberapa skenario percobaan training untuk mendapatkan akurasi terbaik ditunjukkan pada Tabel 3.

Tabel 3. Hasil pelatihan sistem prediksi implan

\begin{tabular}{cccccc}
\hline Epoch & Lr $(\boldsymbol{\alpha})$ & Data Training & Jumlah Hidden Layer & Momentum & Akurasi \\
\hline 10 & 0,1 & 514 & 1 & 0,9 & $91,5 \%$ \\
50 & 0,1 & 514 & 1 & 0,9 & $94 \%$ \\
100 & 0,1 & 514 & 1 & 0,9 & $95,3 \%$ \\
500 & 0,1 & 514 & 1 & 0,9 & $95,4 \%$ \\
1.000 & 0,1 & 514 & 1 & 0,9 & $95,4 \%$ \\
10 & 0,1 & 514 & 2 & 0,9 & $92 \%$ \\
50 & 0,1 & 514 & 2 & 0,9 & $93 \%$ \\
100 & 0,1 & 514 & 2 & 0,9 & $93,3 \%$ \\
500 & 0,1 & 514 & 2 & 0,9 & $94,5 \%$ \\
1.000 & 0,1 & 524 & 2 & 0,9 & $95,3 \%$ \\
10 & 0,1 & 524 & 3 & 0,9 & $92 \%$ \\
50 & 0,1 & 524 & 3 & 0,9 & $95 \%$ \\
100 & 0,1 & 524 & 3 & 0,9 & $96,3 \%$ \\
500 & 0,1 & 524 & 3 & 0,9 & $\mathbf{9 6 , 4} \%$ \\
1.000 & 0,1 & 524 & 3 & 0,9 & $\mathbf{9 6 , 4} \%$ \\
10 & 0,1 & 524 & 4 & 0,9 & $90 \%$ \\
50 & 0,1 & 524 & 4 & 0,9 & $91 \%$ \\
100 & 0,1 & 524 & 4 & 0,9 & $92 \%$ \\
500 & 0,1 & 524 & 4 & 0,9 & $94 \%$ \\
1.000 & 0,1 & 524 & 4 & 0,9 & $94 \%$ \\
\hline
\end{tabular}

\subsection{Hasil Pengujian Sistem Prediksi}

Hasil pengujian prediksi implan dengan NN Backpropagation menggunakan 30 data testing yang terdiri dari 28 daya mayor dan 2 data minor. Model NN Backpropagation menggunakan arsitektur terbaik berdasarkan hasil pengujian, yaitu 3 hidden layer, learning rate $(\boldsymbol{\alpha})=\mathbf{0}, \mathbf{1}$, Momentum $=\mathbf{0}, \mathbf{9}$ dan data dilakukan 5 kali percobaan testing pada 10,50,100,500, dan $\mathbf{1 . 0 0 0}$ epoch didapat nilai akurasi terbaik sebesar 96\% pada 500 dan $\mathbf{1 . 0 0 0}$ epoch. Beberapa skenario percobaan testing untuk mendapatkan akurasi terbaik ditunjukkan pada Tabel 4.

\subsection{Evaluasi Kinerja Sistem Prediksi dengan Metode Confusion Matrix}

Evaluasi menggunakan 544 data, yang terdiri dari 30 data testing ( 2 data minor, 28 data mayor) dan 514 data training (257 data mayor, 13 data minor asli dan 244 data minor buatan). Evaluasi dilakukan dengan 5 kali percobaan, yaitu 10, 50, 100, 500 dan 1.000 epoch. Dari hasil percobaan tersebut, diperoleh nilai akurasi terbaik sebesar 96,1\% pada epoch 500 dan 1.000. Hasil Evaluasi kinerja sistem prediksi implan ditunjukkan pada Gambar 5.

Dengan menggunakan Persamaan 14, Persamaan 15, dan Persamaan 16, maka nilai akurasi, presisi, dan recall ditampilkan pada Tabel 4. Dari hasil percobaan epoch 10, 50, 100, 500, dan 1.000 sesuai 
dengan Tabel 5 didapat nilai tertinggi dari akurasi, presisi, dan recall, yaitu 96,1\%, 97,2\%, dan 95,5\% pada epoch 500 dan 1.000 .

\begin{tabular}{|c|c|c|c|c|c|c|c|c|c|}
\hline \multicolumn{2}{|c|}{ Epoch $=10$} & \multicolumn{2}{|c|}{ Epoch $=50$} & \multicolumn{2}{|c|}{ Epoch $=100$} & \multicolumn{2}{|c|}{ Epoch $=500$} & \multicolumn{2}{|c|}{ Epoch $=1000$} \\
\hline 265 & 20 & 277 & 8 & 277 & 8 & 277 & 8 & 277 & 8 \\
\hline 18 & 241 & 18 & 241 & 16 & 243 & 13 & 246 & 13 & 246 \\
\hline \multicolumn{2}{|c|}{ Accuracy $=93 \%$} & \multicolumn{2}{|c|}{ Accuracy $=95.2 \%$} & \multicolumn{2}{|c|}{ Accuracy $=95.6 \%$} & \multicolumn{2}{|c|}{ Accuracy $=96.1 \%$} & \multicolumn{2}{|c|}{ Accuracy $=96.1 \%$} \\
\hline
\end{tabular}

Gambar 5. Pengukuran Kinerja sistem prediksi dengan confusion matrix

Tabel 4. Hasil pengujian sistem prediksi implan

\begin{tabular}{cccccc}
\hline Epoch & Lr $(\boldsymbol{\alpha})$ & Data Testing & Jumlah Hidden Layer & Momentum & Akurasi \\
\hline 10 & 0,1 & 30 & 1 & 0,9 & $90,5 \%$ \\
50 & 0,1 & 30 & 1 & 0,9 & $93 \%$ \\
100 & 0,1 & 30 & 1 & 0,9 & $94,3 \%$ \\
500 & 0,1 & 30 & 1 & 0,9 & $95 \%$ \\
1.000 & 0,1 & 30 & 1 & 0,9 & $95 \%$ \\
10 & 0,1 & 30 & 2 & 0,9 & $91 \%$ \\
50 & 0,1 & 30 & 2 & 0,9 & $93 \%$ \\
100 & 0,1 & 30 & 2 & 0,9 & $94,3 \%$ \\
500 & 0,1 & 30 & 2 & 0,9 & $94,5 \%$ \\
1.000 & 0,1 & 30 & 2 & 0,9 & $95 \%$ \\
10 & 0,1 & 30 & 3 & 0,9 & $93 \%$ \\
50 & 0,1 & 30 & 3 & 0,9 & $95 \%$ \\
100 & 0,1 & 30 & 3 & 0,9 & $95,6 \%$ \\
500 & 0,1 & 30 & 3 & 0,9 & $96,0 \%$ \\
1.000 & 0,1 & 30 & 3 & 0,9 & $96,0 \%$ \\
10 & 0,1 & 30 & 4 & 0,9 & $93 \%$ \\
50 & 0,1 & 30 & 4 & 0,9 & $93,3 \%$ \\
100 & 0,1 & 30 & 4 & 0,9 & $93,5 \%$ \\
500 & 0,1 & 30 & 4 & 0,9 & $95,4 \%$ \\
1.000 & 0,1 & 30 & 4 & 0,9 & $95,4 \%$ \\
\hline
\end{tabular}

Tabel 5. Hasil pengujian sistem prediksi implan

\begin{tabular}{ccccccccc}
\hline Epoch & TP & TN & FP & FN & Jumlah data & Akurasi & Presisi & Recall \\
\hline 10 & 265 & 241 & 20 & 18 & 544 & $93 \%$ & $93 \%$ & $93,6 \%$ \\
50 & 277 & 241 & 8 & 18 & 544 & $95,2 \%$ & $97,2 \%$ & $93,9 \%$ \\
100 & 277 & 243 & 8 & 16 & 544 & $95,6 \%$ & $97,2 \%$ & $94,5 \%$ \\
500 & 277 & 246 & 8 & 13 & 544 & $96,1 \%$ & $97,2 \%$ & $95,5 \%$ \\
1.000 & 277 & 246 & 8 & 13 & 544 & $96,1 \%$ & $97,2 \%$ & $95,5 \%$ \\
\hline
\end{tabular}

\subsection{Evaluasi Kinerja Sistem Prediksi dengan Metode 10-Fold Cross Validation}

Evaluasi dengan metode 10-fold cross validation dilakukan dengan 5 kali percobaan, yaitu 10, 50, 100, 500, dan 1.000 epoch dengan model 10-fold cross validation berupa linear sampling, shuffle sampling, dan stratified sampling. Dari hasil percobaan tersebut, diperoleh nilai akurasi terbaik sebesar 95\% pada epoch 500. Hasil evaluasi kinerja sistem dengan 10-fold cross validation ditunjukkan pada Tabel 6.

Dari percobaan dua metode evaluasi, yaitu confusion matrix dan 10-fold cross validation, didapat bahwa evaluasi dengan confusion matrix menghasilkan nilai akurasi lebih baik, yaitu 96,1\% daripada metode 10-fold cross validation dengan nilai akurasi terbaiknya $95 \%$.

Tabel 6. Hasil evaluasi sistem prediksi dengan 10-fold cross validation

\begin{tabular}{cccccc}
\hline \multirow{2}{*}{ Tipe Fold } & \multicolumn{5}{c}{ Nilai akurasi berdasarkan jumlah epoch } \\
\cline { 2 - 6 } & $\mathbf{1 0}$ & $\mathbf{5 0}$ & $\mathbf{1 0 0}$ & $\mathbf{5 0 0}$ & $\mathbf{1 . 0 0 0}$ \\
\hline Linear Sampling & $86 \%$ & $93,6 \%$ & $93,1 \%$ & $\mathbf{9 5 \%}$ & $94,7 \%$ \\
Shuffle Sampling & $89,3 \%$ & $92,4 \%$ & $92,1 \%$ & $94,7 \%$ & $\mathbf{9 5 \%}$ \\
Stratified Sampling & $88,3 \%$ & $93 \%$ & $93,5 \%$ & $\mathbf{9 5 \%}$ & $\mathbf{9 5 \%}$ \\
\hline
\end{tabular}




\subsection{Perbandingan Nilai Akurasi Data dengan Teknik SMOTE dan yang Tidak Dilakukan Proses SMOTE dalam Menangani Imbalance Class}

Sistem prediksi pemakaian alat kontrasepsi implan menggunakan kombinasi SMOTE dan NN Backpropagation pada data imbalance class menghasilkan nilai akurasi prediksi yang sangat baik, yaitu $96,1 \%$. Metode SMOTE bekerja dengan baik dalam menangani imbalance class. Hal ini terbukti dari kenaikan nilai akurasi yang cukup signifikan, sedangkan data imbalance class yang tidak dilakukan proses SMOTE nilai akurasinya cenderung tinggi $(100 \%)$ pada kelas mayor, tetapi rendah pada kelas minor $(0 \%)$. Data imbalance class yang tidak dilakukan proses SMOTE menghasilkan prediksi $100 \%$ pada kelas mayor, tetapi tidak berhasil mendeteksi kelas minor (0\%) seperti yang ditunjukkan perbandingan confusion matrix pada Gambar 5 dan Gambar 6.

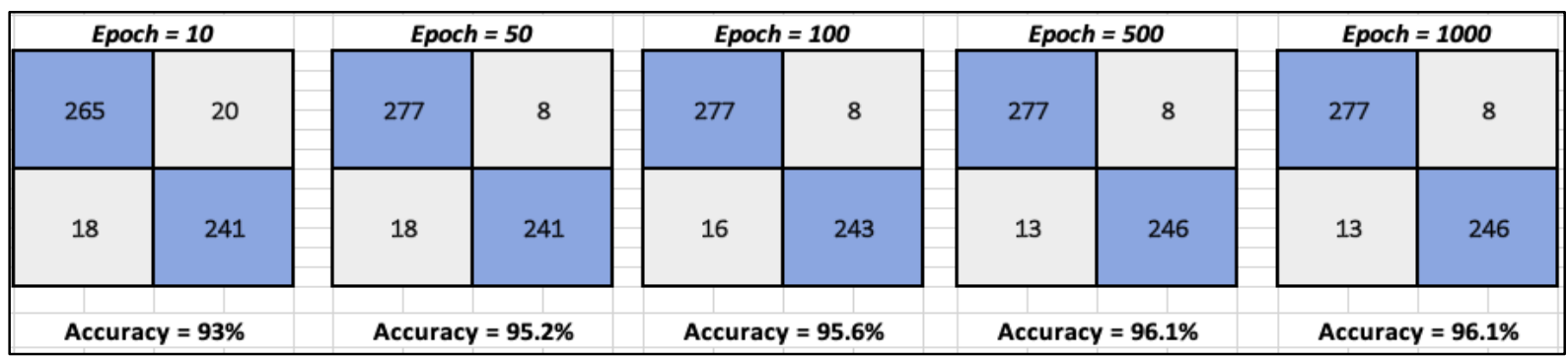

Gambar 6. Confusion matrix akurasi prediksi dengan metode SMOTE.

\begin{tabular}{|c|c|c|c|c|c|c|c|c|c|}
\hline \multicolumn{2}{|c|}{ Epoch $=10$} & \multicolumn{2}{|c|}{ Epoch $=50$} & \multicolumn{2}{|c|}{ Epoch $=100$} & \multicolumn{2}{|c|}{ Epoch $=500$} & \multicolumn{2}{|c|}{ Epoch $=1000$} \\
\hline 285 & 0 & 285 & 0 & 285 & 0 & 285 & 0 & 285 & 0 \\
\hline 15 & 0 & 15 & 0 & 15 & 0 & 15 & 0 & 15 & 0 \\
\hline
\end{tabular}

Gambar 7. Confusion matrix akurasi prediksi dengan tanpa metode SMOTE.

Tabel 7. Nilai akurasi, presisi, dan recall data imbalance class dengan teknik SMOTE

\begin{tabular}{ccccccccc}
\hline Epoch & TP & TN & FP & FN & Jumlah data & Akurasi & Presisi & Recall \\
\hline 10 & 265 & 241 & 20 & 18 & 544 & $93 \%$ & $93 \%$ & $93,6 \%$ \\
50 & 277 & 241 & 8 & 18 & 544 & $95,2 \%$ & $97,2 \%$ & $93,9 \%$ \\
100 & 277 & 243 & 8 & 16 & 544 & $95,6 \%$ & $97,2 \%$ & $94,5 \%$ \\
500 & 277 & 246 & 8 & 13 & 544 & $96,1 \%$ & $97,2 \%$ & $95,5 \%$ \\
1.000 & 277 & 246 & 8 & 13 & 544 & $96,1 \%$ & $97,2 \%$ & $95,5 \%$ \\
\hline
\end{tabular}

Tabel 8. Nilai akurasi, presisi, dan recall data imbalance class tanpa teknik SMOTE

\begin{tabular}{ccccccccc}
\hline Epoch & TP & TN & FP & FN & Jumlah data & Akurasi & Presisi & Recall \\
\hline 10 & 285 & 0 & 0 & 15 & 300 & $95 \%$ & $100 \%$ & $95 \%$ \\
50 & 285 & 0 & 0 & 15 & 300 & $95 \%$ & $100 \%$ & $95 \%$ \\
100 & 285 & 0 & 0 & 15 & 300 & $95 \%$ & $100 \%$ & $95 \%$ \\
500 & 285 & 0 & 0 & 15 & 300 & $95 \%$ & $100 \%$ & $95 \%$ \\
1.000 & 285 & 0 & 0 & 15 & 300 & $95 \%$ & $100 \%$ & $95 \%$ \\
\hline
\end{tabular}

Gambar 6 merupakan hasil confusion matrix akurasi prediksi implan dengan metode SMOTE menggunakan 544 data, yang terdiri dari 30 data testing ( 2 data minor, 28 data mayor) dan 514 data training (257 data mayor, 13 data minor asli dan 244 data minor buatan). Pada epoch 10, 50, 100, 500, dan 1.000 dengan nilai akurasi 93\%; 95,2\%; 95,6\%; 96,1\%; dan 96,1\%, terjadi kenaikan nilai akurasi. Sistem dapat memprediksi kelas minor (target kelas $=1$ ) dengan persentase $93 \%$ kelas minor pada epoch 10 dan 50, sedangkan pada epoch 100 sistem mampu memprediksi 94\% serta 95\% pada epoch ke 500 dan 1.000 . Gambar 7 merupakan hasil akurasi prediksi implan tanpa menggunakan SMOTE menggunakan 300 data yang terdiri dari 285 data mayor dan 15 data minor. Sistem memprediksi dengan nilai akurasi cenderung tinggi pada kelas mayor $100 \%$ (target kelas $=0$ ), tetapi tidak mampu memprediksi kelas minor $(0 \%)$ (target kelas $=1$ ). Pada semua epoch 10, 50, 100, 500, dan 1.000 sistem tidak mampu memprediksi kelas minor $(0 \%)$ (target kelas $=1)$, sedangkan nilai akurasi rata-rata dari keseluruhan data 
cenderung tetap, yaitu 95\% pada epoch 10, 50, 100, 500, dan 1.000. Perbandingan tingkat akurasi data imbalance dengan teknik SMOTE dan yang tanpa SMOTE ditunjukkan pada Tabel 7 dan Tabel 8.

Tabel 6 merupakan nilai akurasi, presisi, dan recall data imbalance class dengan teknik SMOTE. Data dilakukan 5 kali percobaan, yaitu 10, 50, 100, 500 dan 1.000 epoch. Diperoleh nilai terbaik dari akurasi, presisi, recall pada data imbalance class dengan teknik SMOTE sebagai berikut: 96,1\%; 97,2\%; 95,5\% pada 500 dan 1.000 epoch. Tabel 6 merupakan nilai akurasi, presisi, dan recall pada data imbalance class tanpa teknik SMOTE diperoleh nilai akurasi, presisi, dan recall berturut-turut 95\%, 100\%, dan 95\% pada semua percobaan $(10,50,100,500$, dan 1.000 epoch). Data imbalance class tanpa teknik SMOTE memprediksi data mayor dengan dengan nilai akurasi $100 \%$, tetapi nilai akurasi prediksi pada kelas minor $0 \%$. Hal ini dapat dilihat pada Tabel 7 (nilai $\boldsymbol{T N}=\mathbf{0}$ pada semua percobaan $e p o c h$ ). Implementasi kombinasi SMOTE dan NN Backpropagation mampu memprediksi keberhasilan pemakaian alat kontrasepsi implan dengan nilai akurasi $96,1 \%$ sesuai dengan tujuan penelitian ini.

\subsection{Perbandingan Nilai Akurasi Algoritma Klasifikasi dalam Menangani Data Tidak Seimbang (Imbalance Data)}

Perbandingan nilai akurasi algoritma klasifikasi yang mana data penelitian mendapatkan proses SMOTE kemudian diprediksi dengan algoritma klasifikasi, yaitu NN, DT, SVM, dan LR. Metode evalusi yang digunakan, yaitu 10-fold cross validation dengan 3 model sampling (linear sampling, shuffle sampling, dan stratified sampling). Perbandingan nilai akurasi algoritma klasifikasi dalam menangani data tidak seimbang disajikan dalam Tabel 9.

Tabel 9. Perbandingan nilai akurasi algoritma klasifikasi dalam menangani imbalance class

\begin{tabular}{ccccc}
\hline \multirow{2}{*}{ Model Fold } & \multicolumn{4}{c}{ Perbandingan Nilai Akurasi Algoritma Klasifikasi } \\
\cline { 2 - 5 } & SMOTE + NN & SMOTE + DT & SMOTE+SVM & SMOTE +LR \\
\hline Linear Sampling & $94,7 \%$ & $95 \%$ & $78 \%$ & $83 \%$ \\
Shuffle Samplig & $95 \%$ & $96,9 \%$ & $55 \%$ & $85 \%$ \\
Stratified Sampling & $95 \%$ & $95,4 \%$ & $49 \%$ & $85 \%$ \\
\hline
\end{tabular}

Tabel 9 merupakan hasil perbandingan nilai akurasi algoritma klasifikasi dalam menangani imbalance class. Kombinasi SMOTE dan NN menghasilkan nilai akurasi yang lebih baik (95\%) dari kombinasi SMOTE+SVM (78\%), SMOTE+LR (85\%), tetapi tidak lebih baik dari kombinasi SMOTE+DT dengan akurasi 96,9\%. Selisih hasil akurasi antara kombinasi SMOTE+NN dan SMOTE+DT tidak begitu jauh, yaitu $1 \%$. Hasil akurasi dari perbandingan algoritma klasifikasi dalam menangani imbalance class bergantung pada kasus dan jumlah data yang ditangani.

\section{Kesimpulan}

Berdasarkan hasil penelitian yang dilakukan, dapat diambil beberapa kesimpulan, di antaranya penerapan metode kombinasi SMOTE dan NN Backpropagation untuk prediksi pemakaian alat kontrasepsi implan menghasilkan akurasi prediksi 96,1\%. Implementasi kombinasi SMOTE dan NN Backpropagation mampu memprediksi pada imbalance class dengan akurasi 96,1\%. Teknik SMOTE mempu memprediksi dengan persentase $93 \%$ kelas minor pada epoch 10 dan 50, sedangkan pada epoch 100, sistem mampu memprediksi 94\% serta 95\% pada epoch ke 500 dan 1.000. Prediksi data imbalance class tanpa teknik SMOTE menghasilkan nilai akurasi yang cenderung tinggi pada kelas mayor 100\% dan tidak berhasil memprediksi kelas minor $0 \%$. NN Backpropagation terbukti mengalami penurunan performa jika menangani imbalance class. Oleh karena itu, penelitian ini dapat dijadikan sebagai referensi bagi penelitian ke depan untuk menangani data tidak seimbang. Berdasarkan hal tersebut, sistem yang dirancang dapat digunakan sebagai acuan untuk melakukan prediksi terkait keberhasilan pemakaian alat kontrasepsi implan.

\section{Referensi}

BKKBN, B. (2013). Pedoman penggerakan KB dan ayoman komplikasi serta kegagalan kontrasepsi. Jakarta: Direktorat Bina Kesertaan KB Jalur Pemerintah.

Budayawan, K., Yuhandri, \& Nurcahyo, G. W. (2019). Implementasi Jaringan Syaraf Tiruan dalam Memprediksi Frekuensi Resonansi Atena Mikrostrip. JTIP: Jurnal Teknologi Informasi dan Pendidikan, 12(1), 33-40. 
Chen, G., Fu, K., Liang, Z., Sema, T., Li, C., \& Tontiwachwuthikul, P. (2014). The genetic algorithm based back propagation neural network for MMP prediction in CO2-EOR process. Fuel, 126(June), 202212.

Chen, L., Fang, B., Shang, Z., \& Tang, Y. (2018). Tackling class overlap and imbalance problems in software defect prediction. Software Quality Journal, 26(1), 97-125.

García, V., Sánchez, J. S., \& Mollineda, R. A. (2012). On the effectiveness of preprocessing methods when dealing with different levels of class imbalance. Knowledge-Based Systems, 25(1), 13-21.

Gholami, M., Cai, N., \& Brennan, R. (2013). An artificial neural network approach to the problem of wireless sensors network localization. Robotics and Computer-Integrated Manufacturing, 29(2013), 96109.

He, H., \& Ma, Y. (2013). Imbalanced Learning: Foundations, Algorithms, and Applications. Canada: Wiley.

Jian, C., Gao, J., \& Ao, Y. (2016). A new sampling method for classifying imbalanced data based on support vector machine ensemble. Neurocomputing, 193(June), 115-122.

Li, H., \& Sun, J. (2012). Forecasting business failure: The use of nearest-neighbour support vectors and correcting imbalanced samples-Evidence from the Chinese hotel industry. Tourism Management, 33(3), 622-634.

Liu, X.-Y., Li, Q.-Q., \& Zhou, Z.-H. (2013). Learning Imbalanced Multi-class Data with Optimal Dichotomy Weights. IEEE 13th International Conference on Data Mining. Dallas, TX, USA: IEEE.

Mutrofin, S., Mu'alif, A., Ginardi, R. V., \& Fatichah, C. (2019). Solution of class imbalance of k-nearest neighbor for data of new student admission selection. International Journal Of Artificial Intelligence Research, 3(2), 47-55.

Purnamasari, R. W., Dwijanto, D., \& Sugiharti, E. (2013). Implementasi Jaringan Syaraf Tiruan Backpropagation Sebagai Sistem Deteksi Penyakit Tuberculosis (TBC). Unnes Journal of Mathematics, 2(2).

Sanguanmak, Y., \& Hanskunatai, A. (2016). Auto-tuning of parameters in hybrid sampling method for class imbalance problem. 2016 International Computer Science and Engineering Conference (ICSEC). Chiang Mai, Thailand: IEEE.

Sermpinis, G., Dunis, C., Laws, J., \& Stasinakis, C. (2012). Forecasting and trading the EUR/USD exchange rate with stochastic Neural Network combination and time-varying leverage. Decision Support Systems, 54(1).

Shen, L., Lin, Z., \& Huang, Q. (2016). Relay Backpropagation for Effective Learning of Deep Convolutional Neural Networks. European Conference on Computer Vision (ECCV 2016) (pp. 467-482). Cham: Springer.

Susanto, A. T. (2012). Aplikasi Diagnosa Kanker Serviks dengan Menggunakan Algoritma Backpropagation. Kupang: STIKOM Uyelindo.

Thammasiri, D., Delen, D., Meesad, P., \& Kasap, N. (2014). A critical assessment of imbalanced class distribution problem: The case of predicting freshmen student attrition. Expert Systems with Applications, 41(2), 321-330.

Widodo, W., Rachman, A., \& Amelia, R. (2014). Jaringan Syaraf Tiruan Prediksi Penyakit Demam Berdarah dengan Menggunakan Metode Backpropagation. Jurnal IPTEK, 18(1), 64-70.

Yap, B. W., Rani, K. A., Rahman, H. A., Fong, S., Khairudin, Z., \& Abdullah, N. N. (2014). An Application of Oversampling, Undersampling, Bagging and Boosting in Handling Imbalanced Datasets. Proceedings of the First International Conference on Advanced Data and Information Engineering (DaEng2013). 285, pp. 13-22. Singapore: Springer.

Zhang, D., Liu, W., Gong, X., \& Jin, H. (2011). A Novel Improved SMOTE Resampling Algorithm Based on Fractal. Journal of Computer information Systems, 7(6), 2204-2211.

Zhu, T., Lin, Y., \& Liu, Y. (2017). Synthetic minority oversampling technique for multiclass imbalance problems. Pattern Recognition, 72(December), 327-340. 